\title{
Supportive Relationship between Teachers and Students and Among Peers
}

\author{
Enkeleda Stefa, PhD. Cand. \\ European University of Tirana, Albania
}

\begin{abstract}
This study highlights the importance how a positive environment at class and school affects the relationship between teachers and students and among peers. The positive spirit in a classroom is a determining component for creating a favorable learning environment. Various studies have come to the conclusion that students learn better in an environment, both supported by teachers and other students. Positive relationships provide support, motivation, and better performance for school students. Besides that, improving students' relationships with teachers has a significant, positive and long-lasting impact on students' social and scholastic development. Different studies have shown that students who experience close, positive, and supportive relationships with their teachers have higher levels of achievements compared to other students who have experienced more conflicting relationships. Primary, secondary and high school students make greater efforts if they learn in environments where teachers and peers support is not lacking. Students of all ages, especially teenagers, are very much influenced by their peers. According to the motivational perspective, positive relationships between students help their engagement towards school, because they meet their needs for belonging and the connection with the environment, nourish positive feelings, important for the good functioning of the individual and their role as students. Support grows a sense of motivation and leads the student towards school success. Peers' support affects motivational elements as self-confidence and academic achievement and significantly affects an effective engagement.
\end{abstract}

Keywords: positive relationship, peer support, teacher support, higher motivation, better performance

\section{Introduction}

During the time that the students spend in the school, they have only one main role model, that of the teacher. This means that the teachers have a great impact in the individual and social development of the students. Teachers, being the second most important grown-up people in the students' life, besides their parents, the relationship created between them help a lot in the overall teaching process and in the development of their learning skills.

From a research that was conducted by Bridget Hamre and Robert Pianta, who kept records for the children of a specific region who were registered in the kindergarten and that also followed their studies at the same region till the $8^{\text {th }}$ grade, came to the conclusion that the teacher-student relationship in the kindergarten (based on the disagreements between the two parties, the student's dependency on the teacher and the way that the teacher felt about the student) defined the student's overall school performance and behavior till the end of the $8^{\text {th }}$ grade. This mostly affected the students that were not that very well-behaved. Even when their ethnic and genitive factors of their behavior and overall performance were taken into consideration, the teacher-student relationship was still something that strongly determined the student's overall performance. According to a different research that was conducted among the children starting from four and a half years of age till they reached the $5^{\text {th }}$ grade, Pianta and his colleagues noticed that the emotional warmth that the teachers offered to the students and the teacher's ability to identify the work according to the student's needs, helped students a lot in subjects such as that of Mathematics and Literature. There are a lot of factors that indicate that there is a strong connection between the quality of the teacher-student relationship, starting with the student's performance in the early years and of his overall performance in the years after that (Woolfolk A. , 2011).

Teachers devoted to their students, even though they have to deal with many students' difficulties and problems, such as different family situations and other problems regarding their abilities and disabilities, must adapt teaching and assessment methods to students' needs. The teacher must always try to explain the abstract things in a way that are realistic and 
understandable to all the students. Besides the academic concepts that the teachers offer to their students, they also have to always pay attention to the students' emotional needs, by boosting their self-esteem and by teaching them to be responsible for what they do. These teachers are able to notice and find out why one of their students seems so tired. They are reflective, which means that they are constantly thinking about certain situations, analyzing what they are doing and the reasons for why they do such things and this analysis helps them in improving their work with the students.

If students are asked to describe a "good teacher", their descriptions determine three qualities. First, good teachers establish good interpersonal relationships - they care about their students. Second, good teachers keep order in class and preserve their authority without being shown rude or rigid. Third, good teachers manage to motivate their students - they are able to make interesting lessons, being creative and innovative, and making students understand and perceive something regarding the lesson (Woolfolk A. , 2011).

Some other researches that were conducted among the middle-school and high school students show that in cases when teachers were helpful, the students have studied more. It seems to be a direct connection between the teacher's support and the students' motivation into studying more.

The improvement of the teacher-student relationships has a great impact to the social and the educational development of the student in the following years. But this is not the only thing that improves the students' overall performance. However, those students who get along really well with their teachers tend to achieve higher results compared to the conflictual students.

Therefore, the students who consult and talk with their teachers regarding specific issues tend to get a higher evaluation from their teachers. As a result, the student tends to believe his teacher more, to be more participating and to behave more properly and all these things lead him to achieving higher academic results. The positive relationships between teachers and students attract the latter to the learning process and help them into promoting their desire to learn (assuming the content of the classroom material is all-inclusive, age-appropriate and well-matched with the student's abilities). The teachers, who establish more positive relationships with students, create a more favorable environment in the classroom in order for the students to learn and fulfill their developmental, emotional and academic needs. The positive relationship that is created between the parties, consisting of few conflicts, high levels of closeness and low support and dependence, results in better adaptation of students to school and it also helps them into promoting their social skills and academic performance. The teachers who have established better relationships with their students have said that their students didn't tend to leave the school but learn and be more participating instead (Kaufman \& Sandilos, 2017).

The quality of the early teacher-student's positive relationship has a long-term impact. Particularly, students who had had more conflicts with their teachers or were more dependent on them during the time they were in kindergarten had lower academic achievements (in math and language courses) and more behavioral problems (for example: worse working habits), during the eighth grade. The biggest impact was on boys rather than on girls (Hamre \& Pianta, 2001).

Further studies showed that the kindergarten children, who were closer to the teachers and had fewer conflicts, developed better social skills during the high school years than the kindergarten children who had had more conflicting relationships in the past (Berry \& O'Connor, 2009).

A recent study, examining the teacher-student relationship during elementary school (first to fifth grade), concluded that close teacher-student relationships were directly related to reading achievements, while conflicting teacher-student relationships were related with low reading achievement (McCormick \& O'Connor, 2014).

Teachers, who follow each student's focused approach (for example: methods that take into account individual student changes, involving decision-making students, who recognize developmental, personal, and student relationships) are able to motivate their students more than teachers who do not follow such methods (Daniels \& Perry, 2003).

Students' group work also requires for the teacher to create a pleasant and a welcoming environment in the classroom. Such assignments require for the students to work together, thus helping them into improving their learning skills and into exchanging valuable information with each other. The teacher's actions in this case are strongly determined by the way that the students respond. The teacher's responsibility is to create a welcoming and warm environment for the students in order for them to understand the value of the group work and by giving them the idea that the teacher is also being part of their work. By maintaining a positive attitude regarding the student-teacher and student-student relationship, it will 
eventually lead to having a warmer and a more welcoming environment in the classroom. If this would always be put into practice, the students would learn how to respect other students' ideas. The teachers should always try to support their students into improving their learning skills and they also should try to create a warm and positive environment so the students working together can learn faster (Musai, 2003).

Teachers should encourage and nurture student motivation in order for them to improve the student's learning process, they should take into account the students' interests, and they should support their ability to grow. Motivating, means to promote people's interest and internal resources, their inner sense of ability, self-esteem, autonomy, and self-realization.

According to different research, students tend to learn more when they are supported not only by their teachers but also by their classmates. Students of every age, and more precisely the teenagers tend to be influenced by their peers' opinions.

If students do not get along with their peers, they tend to not be that much participating during the classes and as a result they get lower grades at the very end (Woolfolk, 2011).

According to another motivating perspective, the positive relationships between the students help their engagement in school because they meet the needs of belonging and the connection with the environment, nourish the positive feelings important to the good functioning of the individual and their role as a student. Peer support affects academic performance, school adaptation, motivation to learn, and pro-social behaviors (Veiga, et al., 2014).

In a study that Estelle and Perdue (2013) conducted with the fifth-grade students, they came to the conclusion that the peer support influences their performance later on in the sixth grade, in their overall behavior (during their work in the classroom) and in their active and effective participation in the class. The researchers interviewed different students to get information regarding their interpretation for the peer support, whereas form the interview that was conducted with the teachers, the researchers evaluated the percentage of the students' participation during the classes. The results showed that the peer support helps a lot when it comes to achieving higher results, especially when it comes to the teenage years. Peer support affects the student's self-esteem and their academic achievements. This kind of support motivates the students and helps them into achieving higher academic results.

Fredricks (2011) defines peers with a positive academic orientation as people who represent a model of learning, share information, explain questions, collaborate, develop a sense of belonging, adopt positive social norms, and show emotional engagement, behavior, and knowledge.

Sometimes, the help of another student who has found the solution to the problem is very useful for a student who has not found it. Placement close to a good student with a not so good student makes it possible to gain knowledge by exchanging explanations, questions, answers and solutions that come together. Students learn through dialogue and discussion of various issues (Woolfolk, 2011).

When peers build constructive relationship among them, they help each other in having a higher motivation, a higher selfesteem and a better academic performance. The inclusion of the students in the school assignments is easily achieved when there is support from both the peers and the teachers (Veiga, et al., 2014).

School and class students are surrounded by other peers and teachers. As such, their opinions and choices are also influenced by the actions, behaviors, and suggestions of these people. The studies regarding the influence of the students in the social context where they are part of are mostly concentrated on the influence that the teachers and parents have on their students rather than the influence that the students have among themselves. However, we will also see that the relationship between the peers has a great impact in the inclusion, motivation and the well-functioning of the students in the learning process.

The interactions with the peers might be related to the school issues or not and it is impossible not to notice the great impact that these interactions have on the motivation or the inclusion of the students at the school. Peers interactions have a great impact on the motivation, inclusion and the overall achievements of the students at the school and this can be achieved via the exchange of the information and models that strengthen the principles and the values of the peers (Ryan, 2000).

Support from peer students also occurs during group tasks or projects. During teamwork, each of the students can succeed, as the tasks are shared and if any of the group members is weaker, it will be assisted and supported by others. Collaborative 
learning not only provides supportive opportunities for students but also enables them to enrich their knowledge by building academic and social skills (Jacobs, Ranandya, \& Power, 2016).

The studies conducted in this field of study show that despite the importance of the peers support, the support that the teachers and the parents give them is way more important when it comes to the students' overall achievement at the school. A study that was conducted among 822 Chinese students, aimed at studying personal and contextual factors affecting student involvement in the learning process, showed that there is a correlation between student involvement in learning and support provided by teachers, parents, and peers. Support from teachers has the greatest impact on students. According to Wentzel (2012), learning occurs in social environments and social support encourages inclusion in the classroom, affecting the emotional and psychological functioning of students. This author suggests that the students' purposes will be guided by the evaluation that is given to them by their peers and their teachers, and when they feel that these two factors are contributing in fulfilling those purposes, they tend to believe more in themselves and as a result they take more responsibilities (Veiga, et al., 2014).

The students embrace the support that they take from their peers and teachers. Having a social and a positive spirit in the classroom contributes into having a more favorable learning environment.

\section{Bibliography:}

[1] Berry, D., \& O'Connor, E. (2009). Behavioral risk, teacher-child relationships, and social skill development across middle childhood: A child-by-environment analysis of change. Journal of Applied Developmental Psychology, Vol. 31(1), 1-14.

[2] Daniels, D., \& Perry, K. (2003). "Learner-centered" according to children. Theory into Practice Vol. 42(2), $102-$ 108.

[3] Estelle, D., \& Perdue, N. (2013). Social support and behavioral and affective school engagement:the effects of peers, parents, and teachers. Psychology in the Schools, Vol. 50(4), 325-339.

[4] Fredricks, J. (2011). Engagement in school and out-of-school contexts: a multidimensional view of engagement. Theory Into Practice, Vol. 50, 327-335.

[5] Hamre, B. K., \& Pianta, R. C. (2001). Early teacher-child relationships and the trajectory of children's school outcomes through eighth grade. Child Development, Vol. 72, 625-638.

[6] Jacobs, G., Ranandya, W., \& Power, M. (2016). Student-Student Interaction. Simple, Powerful Strategies for Student Centered Learning. Springr: Briefs in Education, Vol. 17, 11-18.

[7] Kaufman, S., \& Sandilos, L. (2017). Improving Students' Relationships with Teachers to Provide Essential Supports for Learning. Tratto da American Psychological Association: http://www.apa.org/education/k12/relationships.aspx

[8] McCormick, M., \& O'Connor, E. (2014). Teacher-child relationship quality and academic achievement in elementary school: Does gender matter? Journal of Educational Psychology.

[9] Musai, B. (2003). Metodologji e Mësimdhënies. Tiranë: CDE.

[10] Ryan, A. (2000). Peer Groups as a Context for the Socialization of Adolescents'Motivation, Engagement, and Achievement in School. EDUCATIONAL PSYCHOLOGIST Vol. 35(2), 101-111.

[11] Veiga, F., Wentzel, K., Melo, M., Pereira, T., Faria, L., \& Galvao, D. (2014). Students' engagement in school and peer relations: A literature review. International Perspectives of Psychology and Education, 196-211.

[12] Wentzel, K. (2012). Socio-Cultural Contexts, Social Competence, and Engagement at School. Handbook of Research on Student Engagement, 479-488.

[13] Woolfolk, A. (2011). Psikologji Edukimi. Tiranë: CDE. 